\title{
Influence of Some Sugars on Xylanase Production by Aspergillus awamori in Solid State Fermentation.
}

\author{
Judith Liliana Solórzano Lemos ${ }^{1 *}$ and Nei Pereira Junior ${ }^{2}$ \\ ${ }^{I}$ Coordenação de Metalurgia Extrativa; Centro de Tecnologia Mineral; Avenida Ipê, 900; 21941-590; Ilha da \\ Cidade Universitária - Rio de Janeiro - Brazil. ${ }^{2}$ Departamento de Engenharia Bioquímica; Escola de Química; \\ Universidade Federal do Rio de Janeiro; 21949-900; Ilha da Cidade Universitária - Rio de Janeiro - Brazil
}

\begin{abstract}
Aspergillus awamori showed high extracellular endoxylanase $(100 \mathrm{U} / \mathrm{ml})$ and $\beta$-xylosidase activities (3.5 U/ml) when grown on milled sugar cane bagasse as the principal carbon source without treatment. Partial characterization of xylanases showed that the apparent values of $K_{m}$ were $3.12 \pm 0.05 \mathrm{mg} / \mathrm{ml}$ for endoxylanase (in birchwood xylan) and $0.45 \pm 0.05 \mathrm{mM}$ for $\beta$-xylosidase (in $p$-nitrophenyl $\beta$-D-xylanopiranoside). Corresponding values of $V_{\max }$ were $6.63 \pm 0.02$ and $0.078 \pm 0.02 \mu \mathrm{mol} / \mathrm{min}$. Gradual repression of endoxylanase activity was observed when increasing concentrations of glucose and xylose $(1,2,4,6$ and $8 \mathrm{~g}$ of carbohydrate / $4 \mathrm{~g}$ of sugar cane bagasse) were added to production media. In contrast, $\beta$-xylosidase activity was stimulated using low levels of carbohydrates (1 g xylose or glucosel $4 \mathrm{~g}$ of sugar cane bagasse).
\end{abstract}

Key words: Aspergillus awamori; endoxylanases; $\beta$-xylosidase; catabolic repression

\section{INTRODUCTION}

Amongst xylanolytic microorganisms, filamentous fungi have been more extensively studied, and the genus Aspergillus has been shown to be an efficient producer of xylanases on an industrial scale (Haltrich et al., 1996). Xylanases have been considered for clarifying fruit juices and wines, for food processing in combination with cellulases and for the improvement of the nutritional properties of agricultural silage and grain feed. Its main potential application though, relates to cellulosic pulp treatment where the biocatalyst has already been incorporated into commercial bleach sequences (Carmona et al., 1997).

The bioconversion of lignocellulosic materials to fermentable sugars for fuel alcohol production has been hindered by economical and technical aspects, and by the existence of more competitive sources of carbohydrates such as starch and sucrose. Nevertheless, there has been much effort in the sense of developing efficient bioprocesses using such raw materials, particularly those deriving from agricultural residues, which have no production cost attached to them, although costs for collection and transportation of these residues to centralized processing location may be incurred.

Genetic manipulation by classical mutation techniques, and more recently by use of recombinant DNA technology, have been used to increase the expression levels of a large number of microbial proteins (Walsh and Headon, 1994). Nonetheless, the use of modern techniques to improve the production of metabolites neither invalidate the search for wild microorganisms nor

\footnotetext{
* Author for correspondence
} 
the effort to evaluate the potential of those already known to produce useful metabolites. Several enzymes are synthesized always, regardless of the conditions of the medium; they are constitutive enzymes. In contrast to these, there are inducible and repressible enzymes. The enzymes involved in substrate degradation are generally inducible. They are formed only when the corresponding substrate is present in the nutrient solution (Schlegel, 1989). Fungal, bacterial and actinomycete xylanolytic enzymes are generally induced by xylan, xylobiose, xylose and by lignocellulosic residues that contain xylan (Flores et al,. 1996; Archana and Satyanarayana, 1997; Kermnický and Biely, 1998).

The extension of induction is dependent upon the nature and the concentration of these carbon sources. An increase in substrate concentration is usually favorable to product synthesis, however, many fermentation products are subjected to carbon catabolite repression, that is, repression of the enzyme synthesis by easily metabolizable sugar (Piñaga et al., 1994; Flores et al,. 1996; Kadowaki et al., 1997; Archana and Satyanarayana, 1997; Kermnický and Biely, 1998). This phenomenon has been evidenced in many microorganisms, and widely studied in Saccharomyces cerevisiae. Nevertheless, the mechanism by which CREA (mediating factor for carbon catabolite repression) mediate glucose repression in filamentous fungi is not wholly understood (Ruijter and Visser, 1997). It is possible that the mechanism in filamentous fungi has some similarity to that in S. cerevisiae, where glucose repression is mediated by a protein that involves nucleosome positioning (Archer and Peberdy, 1997).

Considering the industrial importance of xylanases, the present study evaluated the use of milled sugar cane bagasse as carbon source, and the influence of xylose and glucose on the production of these enzymes by Aspergillus awamori.

\section{MATERIALS AND METHODS}

\section{Organism and growth conditions}

Aspergillus awamori was maintained on sterile sand for conservation. Conidia were generated by growing the fungus on agar tubes with Czapeck media. After 5-6 day cultivation at $30{ }^{\circ} \mathrm{C}$, conidia were scrapped off and transferred to sterile distilled water. This conidia suspension was used for medium inoculation in a final concentration of $5 \times 10^{6}$ conidia/g bagasse.

\section{Growth media and culture conditions}

Fermentations for enzyme production were carried out in $500 \mathrm{ml}$ conical flasks containing $4 \mathrm{~g}$ of roughly $1 \mathrm{~mm}$-sized dry sugar cane bagasse, ground in a disc mill (Perten, Laboratory mill 3600). The sugar cane bagasse was moistened with $50 \mathrm{ml}$ of an aqueous solution composed of $(\mathrm{g} / 4 \mathrm{~g}$ of bagasse): $\mathrm{NaNO}_{3}, 0.39$; yeast extract, $0.5 ; \mathrm{NaCl}$, $0.2 ; \mathrm{KH}_{2} \mathrm{PO}_{4}, 0.2 ; \mathrm{MgSO}_{4} 7 \mathrm{H}_{2} \mathrm{O}, 0.04$. The flasks were incubated in na incubator (FANEM, Retilinea, Brazil) at $30^{\circ} \mathrm{C}$ for 2.5 to 6 days when their whole content was extracted by adding 100 $\mathrm{mL}$ of distilled water. After a period of 30 minutes under agitation at $150 \mathrm{rpm}$ and room temperature, the supernatant was separated by filtration and used for determination of enzymatic activities.

\section{Enzymatic assays}

Endoxylanase was determined by measuring the reducing sugars from hydrolysis of birchwood xylan (Sigma, St Louis, MO). $0.9 \mathrm{ml}$ solution of $1 \%$ xylan was pre-incubated in $50 \mathrm{mM}$ citrate phosphate buffer, $\mathrm{pH} 5$, for $2 \mathrm{~min}$ at $60^{\circ} \mathrm{C}$. To this solution, $0.1 \mathrm{ml}$ of the diluted crude enzyme was added and the reaction stopped after $2 \mathrm{~min}$ by the addition of $1 \mathrm{ml}$ DNS solution. One unit of activity was defined as the amount of enzyme required to release $1 \mu \mathrm{mol}$ of reducing sugar (xylose) per minute. $\beta$-xylosidase activity was determined by measuring the release of $p$-nitrophenol from $p$ nitrophenyl $\beta$-D-xylanopiranoside (PNPX) from Sigma (St Louis, MO). The enzyme solution (0.1 $\mathrm{ml}$ ) was incubated in a test tube with $0.5 \mathrm{ml}$ of $1.25 \mathrm{mM}$ PNPX (pre-incubated for $2 \mathrm{~min}$ ) in 50 $\mathrm{mM}$ phosphate citrate buffer, $\mathrm{pH} 5$ at $55^{\circ} \mathrm{C}$. The reaction was stopped after $10 \mathrm{~min}$ by addition of 4 $\mathrm{ml} \mathrm{Na}_{2} \mathrm{CO}_{3} 0.25 \mathrm{M}$. One unit of activity was defined as the amount of enzyme required to release $1 \mu \mathrm{mol}$ of $\mathrm{p}$-nitrophenol per minute.

\section{Kinetic parameters}

In order to evaluate the kinetic parameters for endoxylanase and $\beta$-xylosidase, a microcomputer program (Oestreicher and Pinto, 1987) was used to 
determine the degradation of birchwood xylan and PNPX using the following concentrations: 0.12 , $0.20,0.60,0.75,1.0,1.50$, and $3.0 \% \mathrm{w} / \mathrm{v}$ for birchwood xylan, and $0.31,0.41,0.63$ and 1.25 $\mathrm{mM}$ for PNPX. Both substrates were incubated with an appropriate diluted crude extract for up to $8 \mathrm{~min}$ for endoxylanase and for up to $130 \mathrm{~min}$ for $\beta$-xylosidase at 60 and $55{ }^{\circ} \mathrm{C}$, respectively. The computer program, written in BASIC can be run on any microcomputer with the $\mathrm{CP} / \mathrm{M}$ operating system. Weighting of observed initial velocities is decided by the user by assessing constant variance, proportional variance or by incorporation of the variances calculated by a subroutine. The program also uses robust regression by bisquare weighting. All questions concerning data input, type of rate function, type of weight and the use of bisquare regression appear on the video display unit.

The program can be run on a microcomputer with less than $48 \mathrm{~K}$ of random access memory and is based upon a nonlinear least-square regression method, which uses a re-iterative Gauss-Newton procedure to refine initial estimates of the parameters generated by the same program.

\section{RESULTS}

Xylanases have been widely studied using the most different carbon sources. However, the activity of these enzymes have not been so expressive when the microorganisms were cultivated in sugar cane bagasse without any treatment. Table 1 showed the xylanase production by some of the organisms that used bagasse as carbon substrate. Figure 1 showed the estimation of kinetic parameters using Hanes Wolff plot. An analysis of the apparent kinetic parameters (Table 2) using both the microcomputer program and the Hanes Wolff plot revels that the results do not differ significantly from each other. The role of glucose and xylose as components of the media for xylanase production was also analyzed. Figure 2 showed that the higher the xylose and glucose concentrations were in the culture medium, the higher was the catabolic repression on endoxylanase activity.

Table 1 - Production of endoxylanase and $\beta$-xylosidase induced by sugar cane bagasse without treatment.

\begin{tabular}{|c|c|c|c|c|}
\hline Strains & $\begin{array}{l}\text { Endoxylanase } \\
\quad\left(\mathrm{UL}^{-1} \mathbf{h}^{-1}\right)\end{array}$ & $\beta$-xylosidase & $\begin{array}{l}\text { Fermentation } \\
\quad \text { (time) }\end{array}$ & Reference \\
\hline Aspegillus ochraceus & $\begin{array}{l}8.5 \mathrm{Uml}^{-1}(51) \\
18.6 \mathrm{Uml}^{-1}(48)\end{array}$ & $\begin{array}{l}2.4 \mathrm{Uml}^{-1} \\
3.8 \mathrm{Uml}^{-1}\end{array}$ & $\begin{array}{c}\mathrm{S}^{\mathrm{b}}(7 \text { days }) \\
\mathrm{SS}^{\mathrm{c}}(16 \text { days })\end{array}$ & Biswas et al. 1988 \\
\hline Penicillium janthinellum & $38.2 \mathrm{Uml}^{-1}(796)$ & - & $\mathrm{S}^{\mathrm{b}}(48 \mathrm{~h})$ & Milagres et al. 1993 \\
\hline Aspergillus sydowii & $11.3 \mathrm{Umg}^{-1}$ & $2.2 \mathrm{Umg}^{-1}$ & $\mathrm{~S}^{\mathrm{b}}$ (4 days) & Gosh et al. 1993 \\
\hline Aspergillus sp & $1.9 \mathrm{Uml}^{-1}(16)$ & - & $\mathrm{S}^{\mathrm{b}}$ (5 days) & Wang et al. 1994 \\
\hline $\begin{array}{l}\text { Thermomyceslanuginosus } \\
\text { Thermoascus aurantiacus }\end{array}$ & $\begin{array}{l}824.5 \mathrm{Ug}^{-1}(446) \\
292.6 \mathrm{Ug}^{-1}(158)\end{array}$ & $\begin{array}{l}- \\
-\end{array}$ & $\begin{array}{l}\mathrm{SS}^{\mathrm{c}}(7 \text { days }) \\
\mathrm{SS}^{\mathrm{c}}(7 \text { days })\end{array}$ & Alam et al. 1994 \\
\hline Aspergillus fischeri Fxn1 & $10.7 \mathrm{Uml}^{-1}(111)$ & - & $\mathrm{S}^{\mathrm{b}}$ (4 days) & $\begin{array}{l}\text { Raj and Chandra } \\
1995\end{array}$ \\
\hline Cellulomomas flavigena & $18 \mathrm{Umg}^{-1}$ & $60.0 \mathrm{Umg}^{-1}$ & $\mathrm{~S}^{\mathrm{b}}(40 \mathrm{~h})$ & $\begin{array}{l}\text { Pérez-Avalos et al. } \\
1996\end{array}$ \\
\hline Aspergillus tamarii & 16.7 $\mathrm{Uml}^{-1}(139)$ & $0.28 \mathrm{Uml}^{-1}$ & $\mathrm{~S}^{\mathrm{b}}$ (5 days) & Kadowaki et al. 1997 \\
\hline $\begin{array}{l}\text { Trichoderma reesei } \\
\text { Aspergillus niger } \\
\text { Aspergillus phoenicis } \\
\text { Aspergillus awamori }\end{array}$ & $\begin{array}{c}1900 \mathrm{Ug}^{-1} \mathrm{a} \\
1750 \mathrm{Ug}^{-1} \mathrm{a}(1510) \\
0 \mathrm{Ug}^{-1} \mathrm{a}(0) \\
100 \mathrm{Uml}^{-1}(1660) \\
60.5 \mathrm{Umg}^{-1} \\
3750 \mathrm{Ug}^{-1}\end{array}$ & $\begin{array}{c}- \\
- \\
- \\
3.5 \mathrm{Uml}^{-1} \\
2.1 \mathrm{Umg}^{-1}\end{array}$ & $\begin{array}{l}\mathrm{SS}^{\mathrm{c}}(72 \mathrm{~h}) \\
\mathrm{SS}^{\mathrm{c}}(72 \mathrm{~h}) \\
\mathrm{SS}^{\mathrm{c}}(72 \mathrm{~h}) \\
\mathrm{SS}^{\mathrm{c}}(60 \mathrm{~h})\end{array}$ & $\begin{array}{l}\text { Gutierrez-Correa and } \\
\text { Tengerdy } 1998 \\
\text { Present work }\end{array}$ \\
\hline
\end{tabular}

${ }^{\mathrm{a}}$ Alkali treated bagasse; ${ }^{\mathrm{b}}$ submerged fermentation; ${ }^{\mathrm{c}}$ solid state fermentation. 

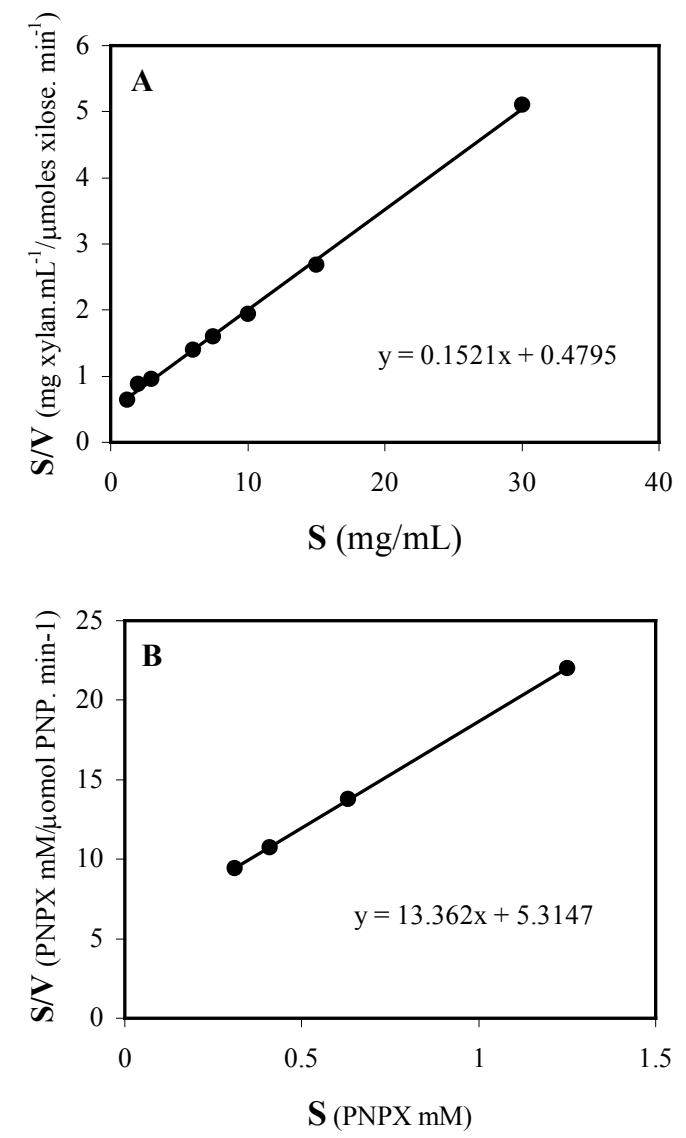

Figure 1 - Hanes Wolff plot for the determination of kinetic parameters for endoxylanase (A) and $\beta$ xylosidase (B).

Table 2 - Comparison of the kinetic parameters obtained from a computer program and Hanes Wolff plot

\begin{tabular}{ccc}
\hline \multicolumn{3}{c}{ Endoxylanase } \\
\hline Methods & $\mathrm{K}_{\mathrm{m}}$ & $\mathrm{V}_{\mathrm{m}}$ \\
Comp. & $3.12 \pm 0.05$ & $6.63 \pm 0.02$ \\
Program & $\mathrm{mg} / \mathrm{ml}$ & $\mu \mathrm{mol} / \mathrm{min}$ \\
Hanes Wolff & $3.15 \pm 0.01$ & $6.57 \pm 0.01$ \\
& $\mathrm{mg} / \mathrm{ml}$ & $\mu \mathrm{mol} / \mathrm{min}$ \\
\hline & $\beta$-xylosidase & \\
\hline Methods & $\mathrm{K}_{\mathrm{m}}$ & $\mathrm{V}_{\mathrm{m}}$ \\
Comp. & $0.45 \pm 0.05$ & $0.078 \pm 0.002$ \\
Program & $\mathrm{mM}$ & $\mu \mathrm{mol} / \mathrm{min}$ \\
& & $0.075 \pm 0.001$ \\
Hanes Wolff & $0.4 \pm 0.01$ & $\mu \mathrm{mol} / \mathrm{min}$ \\
\hline
\end{tabular}

to affect negatively the enzymatic synthesis of many microorganisms (Flores et al, 1996; Archana and Satyanarayana, 1997). Nevertheless, the influence of low concentrations of these carbohydrates on $\beta$-xylosidase production (Figures 2C and 2D) displayed different behavior. Apparently, they stimulated the enzyme activity. The time course of $\beta$-xylosidase production by A. awamori was studied in experiments containing $1 \mathrm{~g}$ of xylose or glucose / $4 \mathrm{~g}$ of bagasse (Figure 3). Results were compared with those obtained in a control experiment without any other carbon source, and they corroborated that low concentrations of easily metabolizable sugars improved the level of $\beta$-xylosidase production.

\section{DISCUSSION}

Table 1 showed extracellular xylanase production by several microorganisms. Our results showed that A. awamori grown on an inexpensive and abundant natural substrate in Brazil was able to produce high levels of hydrolytic enzymes, specially endoxylanase $(100 \mathrm{U} / \mathrm{ml})$ to a greater extent than other microorganisms also inoculated on untreated sugar cane bagasse. It could be important to point out that the superiority of xylanase production by $A$. awamori might be also evidenced by the volumetric productivity, $1660 \mathrm{UL}^{-1} \mathrm{~h}^{-1}$ for endoxylanase (Table 1). According to Gosh et al. (1993), agricultural residues efficiently induced the production of xylanases. In agreement with this, it could be noted that the results obtained with $A$. awamori reflected the high potential of sugar cane bagasse as an external stimulus on the production of xylanase.

The data presented in Figure 2A and 2B showed that the biosynthesis of endoxylanase decreased gradually when increasing concentrations of glucose or xylose were added. This inhibition of endoxylanase synthesis could be interpreted in terms of catabolite repression likewise described for other enzymes (Beguin and Aubert, 1994; Pereira-Meirelles et al. 1997; Siqueira et al. 1997; Kermnický and Biely, 1998). Catabolite repression refers to the repression of enzyme synthesis by glucose or other easily metabolized sugars.

Addition of glucose and xylose to the culture media containing another carbon source is known 

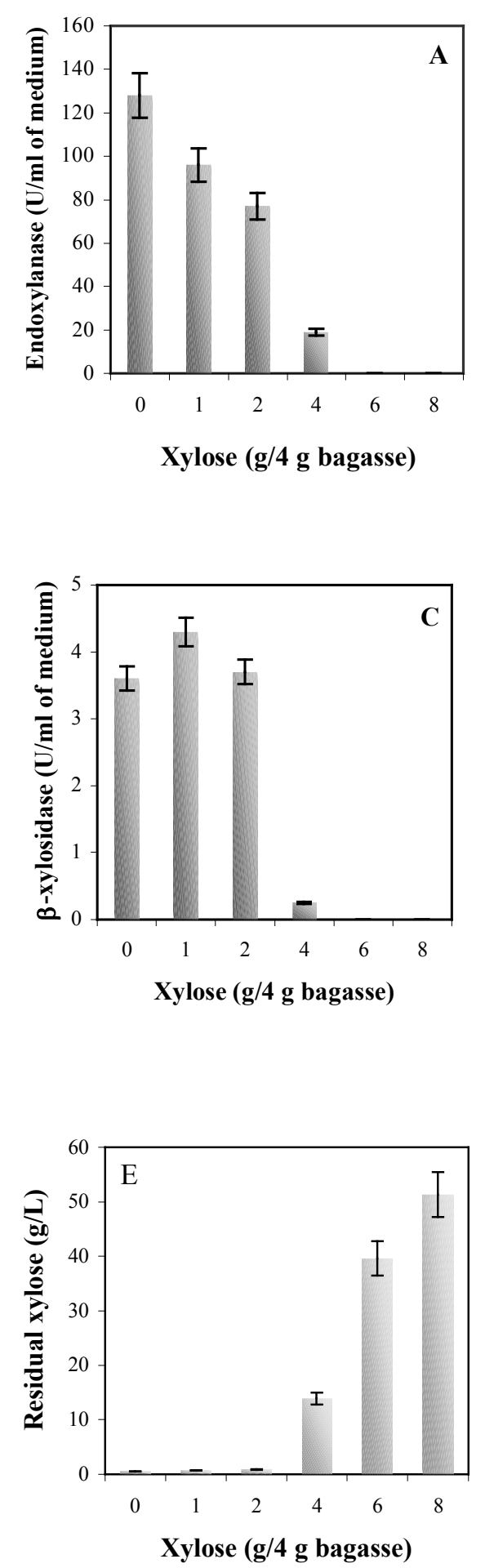
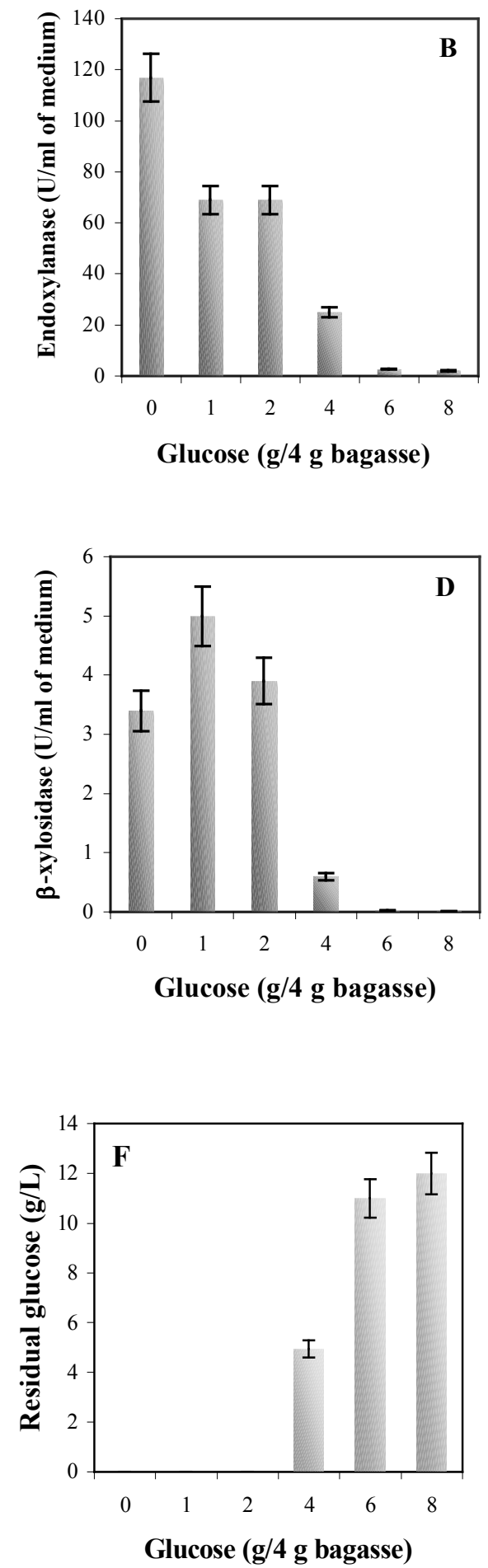

Figure 2 - Effect of xylose and glucose concentrations on endoxylanase (A and B) and $\beta$-xylosidase (C and $\mathrm{D}$ ) production by $A$. awamori growing on sugar cane bagasse (4g/flask), on batch fermentation, during 2.5 days at $30^{\circ} \mathrm{C}$, and $\mathrm{pH} 5.5$. Residual xylose (E) and glucose (F) were also measured. 


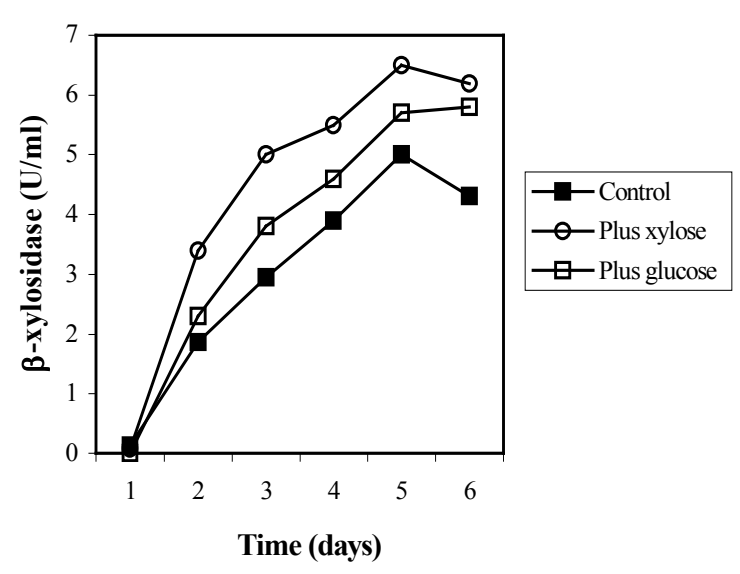

Figure 3 - Time course of $\beta$-xylosidase during incubation of $A$. awamori in media containing bagasse $(\boldsymbol{\square})$; bagasse plus $1 \mathrm{~g}$ xylose/4 g bagasse $(\mathrm{O})$, and bagasse plus $1 \mathrm{~g}$ glucose $/ 4 \mathrm{~g}$ bagasse ( ).

It is believed that some product of glucose metabolism, rather than glucose itself, is involved, because of the analogous effects of other easily metabolized sugars.

In contrast to the result obtained with endoxylanases, addition of $1.0 \mathrm{~g}$ xylose or glucose / $4 \mathrm{~g}$ of sugar cane bagasse caused an unusual increase in $\beta$-xylosidase expression, and $2.0 \mathrm{~g}$ xylose or glucose $/ 4 \mathrm{~g}$ of sugar cane bagasse did not cause any effect on the activity of the enzyme when compared to the control (Figures $2 \mathrm{C}$ and 2D). However, 4.0, 6.0 and $8.0 \mathrm{~g}$ xylose or glucose $/ 4 \mathrm{~g}$ of sugar cane bagasse strongly repressed $\beta$-xylosidase production.

These results suggested that a low supply of any easily metabolizable sugar triggered $\beta$-xylosidase induction. According to Flores et al. (1996), xylose has two possible effects. If xylose is added as sole carbon source it induces $\beta$-xylosidase biosynthesis, if xylose is added to a medium containing birchwood xylan it affects the enzymatic synthesis negatively, probably acting as end product repressor. Concerning to endoxylanase, probably, the repression by glucose or xylose is not solely related to the presence of sugar in the media (Figures 2E and 2F), considering that at low concentrations, carbohydrates were almost completely consumed. It was noted that although the consumption of glucose was higher than the consumption of xylose, the repressive effect on the activity of endoxylanase was similar for both monosaccharides.
Unfortunately, it is not yet possible to set down a final version of the repression mechanism complete in all respects. It is possible, however, to present, in outline, features of the process which are probably quite valid. In the first place, it is believed that all regulation of enzyme synthesis takes place by means of repression. Furthermore, repression seems to take place at the level of transcription of information between DNA and mRNA, by interfering with the synthesis of mRNA at the DNA template. Therefore, repression leads to a failure to make mRNA as well as protein (Gadd, 1988).

The time course of $\beta$-xylosidase production was studied in a following experiment to corroborate those results (Figure 3). Once again it was demonstrated that $\beta$-xylosidase biosynthesis was positively affected by low concentrations of carbon sources, probably by supporting the fungus growth, and thus allowing a higher production. Sunna and Antranikia (1997) commented that most of the reported $\beta$-xylosidases are completely inhibited by xylose. Nevertheless, in contrast to that consideration, A. awamori was able to produce a considerable amount of this enzyme when grown in media containing low xylose or glucose concentrations.

From the results presented in this study it is evident that, xylanases can be produced by developing an inexpensive process in solid state fermentation on sugar cane bagasse. The endoxylanase activity reported in this paper is higher than those reported by other researches using the same raw material. In addition, xylose and glucose exerted catabolic repression on endoxylanase but not on $\beta$-xylosidase activity at low concentrations.

\section{RESUMO}

O cultivo de Aspergillus awamori em bagaço de cana, finamente dividido e sem tratamento prévio, favoreceu a produção de níveis elevados de endo-xilanase $\quad(100 \mathrm{U} / \mathrm{ml})$ e $\beta$-xilosidase $(3.5 \mathrm{U} / \mathrm{ml})$ extracelulares. A caracterização parcial das enzimas xilanolíticas permitiu estabelecer os parâmetros cinéticos aparentes, sendo $\mathrm{K}_{\mathrm{m}}$ igual a $3.12 \pm 0.05 \mathrm{mg} / \mathrm{ml}$ para endox-xilanase (xilana birchwood) e $0.45 \pm 0.05 \mathrm{mM}$ para $\beta$-xylosidase (p-nitrofenil $\quad \beta$-D-xilanopiranosideo). Os correspondentes valores de $V_{m}$ foram 
$6.63 \pm 0.02$ e $0.078 \pm 0.02 \mu \mathrm{mol} / \mathrm{min}$. Observou-se uma repressão gradual da atividade endo-xilanásica quando concentrações crescentes de glicose e xilose $(1,2,4,6$ e 8 g de carboidrato / $4 \mathrm{~g}$ de bagaço de cana) foram adicionadas aos meios de produção. Contrariamente, a atividade $\beta$-xilosidásica foi estimulada quando níveis baixos de açúcares simples foram utilizados (1 $\mathrm{g}$ de xilose ou glicose/ $4 \mathrm{~g}$ de bagaço de cana).

\section{REFERENCES}

Alam, M., Gomes, I., Mohiuddin G. and Hoq, M. M. (1994), Production and characterization of thermostable xylanases by Thermomyces lanuginosus and Thermoascus aurantiacus grown on lignocelluloses. Enzyme Microb. Technol., 16, 298-302.

Archana, A. and Satyanarayana, T. (1997), Xylanase production by thermophilic Bacillus licheniformis A99 in solid-state fermentation. Enzyme Microbiol. Technol., 21, 12-17.

Archer, D. B. and Peberdy, J. F. (1997), The molecular biology of secreted enzyme production by fungi. Critical Rev. Biotechnol., 17273-306.

Beguin, P. and Aubert, J. P. (1994), The biological degradation of cellulose. FEMS Microbiol. Rev., 13, 25-58.

Biswas, S. R.; Mishra, A. K. and Nanda, G. (1988), Xylanase and $\beta$-xylosidase production by Aspergillus ochraceus during growth on lignocelluloses. Biotechnol. Bioeng., 31613-616.

Flores, M. E.; Perea, M.; Rodríguez O.; Malváez, A. and Huitrón, C. (1996), Physiological studies on induction and catabolite repression of $\beta$-xylosidase and endoxylanase in Streptomyces sp.CH-M-1035. J. Biotechnol., 49179-187.

Gadd, G. M. (1988), Carbon nutrition and metabolism. In: Berry, D. R. (ed.). Physiology of Industrial Fungi. Blackwell Scientific Publications, Oxford. pp. 21-57.

Ghosh, M.; Das, A.; Mishra, A. K. and Nanda, G. (1993), Aspergillus sydowii MG 49 is a strong producer of thermostable xylanolytic enzymes. Enzyme Microbiol. Technol., 15703-709.

Gutierrez-Correa, M. and Tengerdy, R. P. (1998), Xylanase production by fungal mixed culture solid state fermentation on sugar cane bagasse. Biotechnol. Letter., 20, 45-47.

Haltrich, D.; Nidetzky B.; Kulbe, K. D.; Steiner, W. and Zupancic, S. (1996), Production of fungal xylanases. Bioresource Technol., 58137-161.
Kadowaki, M. K.; Souza, C. G. M.; Simão, R. C. G. and Peralta, R. M. (1997), Xylanase production by Aspergillus tamarii. Appl. Biochem. Biotechnol., 66, 97-106.

Kermnický, L. and Biely, P. (1998), Disaccharides permeases: constituents of xylanolytic and mannanolytic systems of Aureobasidium pullulans. Biochim. Biophys. Acta, 1425, 560-566.

Milagres, A. M. F.; Lacis, L. S. and Prade, R. A. (1993), Characterization of xylanase production by a local isolate of Penicillium janthinellum. Enzyme Microbiol. Technol., 15248-253.

Oestreicher, E. G. O. and Pinto, G. F. (1987), A microcomputer program for fitting enzyme inhibition rate equation. Comput. Biol. Med., 1753-68.

Pereira-Meirelles, F. V.; Rocha-Leão, M. H. M. and Sant'Anna, G. L. (1997), A stable lipase from Candida lipolytica - Cultivation conditions and crude enzyme characteristics. Appl. Biochem. Biotechnol., 63-65, 73-85.

Pérez-Avalos, O.; Ponce-Noyola, T.; Magaña-Plaza, I. and Torre, M. (1996), Induction of xylanase and $\beta$-xylosidase in Cellulomonas flavigena growing on different carbon sources. Appl. Microbiol. Biotechnol., 46, 405-409.

Piñaga, F.; Fernández-Espinar, M. T.; Vallés, S. and Ramón, D. (1994), Xylanase production in Aspergillus nidulans: Induction and catabolite repression. FEMS Microbiol. Lett., 115, 319-324.

Raj, K. C. and Chandra, T. S. (1995), A cellulase-free xylanase from alkali-tolerant Aspergillus fischeri Fxn1. Biotechnol. Letters., 17, 309-314.

Rujtier, G. J. G. and Visser, J. (1997), Carbon repression in Aspergilli. FEMS Microbiol. Lett., 151, 103-114.

Schlegel, H. G. (1989), The Metabolism of Microorganisms. In: Präve, P.; Faust, U.; Sittig, W. and Sukatsch, D. A. (eds). Basic Biotechnology - A Student's Guide. VHC - Publishers. pp. 67-101.

Siqueira, E. M. D.; Mizuta, K. and Giglio, J. R. (1997), Pycnoporus sanguineus: a novel source of a-amylase. Mycol. Res., 101, 188-190.

Sunna, A. and Antranikian, G. (1997), Xylanolytic enzymes from fungi and bacteria. Critical Rev. Biotechnol., 17, 39-67.

Walsh, G. and Hedon, D. (1994), Downstream processing. In: Wiley, John and Sons (eds). Protein Biotechnology. pp.107-109.

Wang, S. L.; Chen, L. G.; Chen, C. S. and Chen, L. F. (1994), Cellulase and xylanase production by Aspergillus sp. G-393. Appl. Biochem. Biotechnol., 45/46, 655-662. 